\title{
FUNGSI GUBERNUR DALAM PENYELENGGARAAN PEMERINTAHAN DI DAERAH
}

\author{
Wilda Prihatiningtyas \\ wilda.fhunair@gmail.com
}

\begin{abstract}
Abstrak
Perkembangan desentralisasi dan otonomi daerah di Indonesia telah mengalami pasang surut mulai sejak jaman kolonial Belanda sampai saat ini. Sejak Indonesia merdeka hingga saat ini sudah ada 8 (delapan) Undang-Undang yang mengatur tentang Pemerintahan Daerah, mulai dari UU No. 1/1945, UU No. $22 / 1948$, UU No. $1 / 1957$, UU No. $18 / 1965$, UU No. $5 / 1974$, UU No. $22 / 1999$, UU No. 32/2004, dan terakhir UU No. 23/2014. Masing-masing UU tersebut memiliki politik hukumnya sendiri yang kemudian berimplikasi pada adanya perbedaan fungsi Gubernur dalam penyelenggaraan sistem pemerintahan di Indonesia. Ada 2 (dua) fungsi dasar yang melekat pada Gubernur. Pertama, yaitu fungsi desentralisasi. Dalam kaitannya dengan fungsi ini, Gubernur berkedudukan sebagai Kepala Daerah Otonom, yang memiliki kewenangan untuk menjalankan urusan rumah tangga daerah dengan sumber pendanaan APBD. Kedua, yaitu fungsi dekonsentrasi. Dalam kaitannya dengan fungsi ini, Gubernur berkedudukan sebagai Wakil Pemerintah Pusat, yang memiliki kewenangan untuk menjalankan urusan pemerintahan (absolut maupun umum) dengan sumber pendanaan APBN.
\end{abstract}

Kata Kunci : Desentralisasi, Dekonsentrasi, Gubernur, Pemerintahan Daerah

\section{A. PENDAHULUAN}

Penyelenggaraan pemerintahan daerah di Indonesia berpijak pada Pasal 18 Ayat (1) UUD NRI 1945, yang menyebutkan bahwa "Negara Kesatuan Republik Indonesia dibagi atas daerah-daerah provinsi dan daerah provinsi itu dibagi atas kabupaten dan kota, yang tiap-tiap provinsi, kabupaten, dan kota itu mempunyai pemerintahan daerah, yang diatur dengan undang-undang.". Makna dari penormaan "negara dibagi" yaitu bahwa negara diartikan sebagai organisasi kekuasaan ${ }^{1}$, sehingga yang dibagi disini adalah kekuasaan atau kewenangan

${ }^{1}$ Pandangan negara sebagai organisasi kekuasaan dipelopori oleh Logemann dalam bukunya Over De Theorie van Een Stelling Staatsrecht. Dalam buku itu, dikatakan bahwa keberadaan Negara bertujuan untuk mengatur serta menyelenggarakan masyarakat yang dilengkapi dengan kekuasaan tertinggi. Pandangan Logemann ini kemudian diikuti oleh Harold J. Laski, Max 
pemerintahan. Pembagian kekuasaan atau kewenangan inilah yang kemudian melahirkan daerah-daerah otonom.

Sejarah pemerintahan di Indonesia sampai saat ini sudah ada 8 (delapan) Undang-Undang yang mengatur tentang Pemerintahan Daerah, mulai dari Undang-undang Nomor 1 Tahun 1945 tentang Kedudukan Komite Nasional Daerah (UU No. 1/1945), Undang-Undang Nomor 22 Tahun 1948 tentang Penetapan Aturan-Aturan Pokok Mengenai Pemerintahan Sendiri Di DaerahDaerah Yang Berhak Mengatur Dan Mengurus Rumah Tangganya Sendiri (UU No. 22/1948), Undang-Undang Nomor 1 Tahun 1957 tentang Pokok-Pokok Pemerintahan Daerah (UU No. 1/1957), Undang-Undang Nomor 18 Tahun 1965 tentang Pokok-Pokok Pemerintahan Daerah (UU No. 18/1965), Undang-Undang Nomor 5 Tahun 1974 tentang Pokok-Pokok Pemerintahan Di Daerah (UU No. 5/1974), Undang-Undang Nomor 22 Tahun 1999 tentang Pemerintahan Daerah (UU No. 22/1999), Undang-Undang Nomor 32 Tahun 2004 tentang Pemerintahan Daerah (UU No. 32/2004), serta yang berlaku sekarang yaitu Undang-Undang Nomor 23 Tahun 2014 tentang Pemerintahan Daerah (UU No. 23/2014) yang telah diubah dengan Undang-Undang Nomor 2 Tahun 2015 tentang Penetapan Peraturan Pemerintah Pengganti Undang-Undang Nomor 2 Tahun 2014 tentang Perubahan atas Undang-Undang Nomor 23 Tahun 2014 tentang Pemerintahan Daerah Menjadi Undang-Undang (UU No. 2/2015), dan terakhir diubah dengan Undang-Undang Republik Indonesia Nomor 9 Tahun 2015 tentang Perubahan Kedua Atas Undang-Undang Nomor 23 Tahun 2014 tentang Pemerintahan Daerah (UU No. 9/2015). Akan tetapi, masalah yang berkaitan dengan otonomi daerah nampaknya tidak pernah selesai. Persoalan yang seringkali muncul

Weber, dan Leon Duguit. Pengertian tersebut, menempatkan Negara sebagai organisasi kekuasaan. Dalam konteks organisasi kekuasaan, di dalam Negara terdapat suatu mekanisme tata hubungan kerja yang mengatur suatu kelompok manusia (rakyat) agar berbuat atau bersikap sesuai dengan kehendak Negara (yang mempunyai kekuasaan). Agar Negara dapat mengatur rakyatnya, Negara diberi kekuasaan yang dapat memaksa seluruh anggotanya untuk mematuhi segala peraturan perundang-undangan yang telah ditetapkan oleh Negara. Untuk menghindari adanya kekuasaan sewenang-wenang, di sisi lain Negara juga menetapkan cara-cara dan batas-batas sampai di mana kekuasaan dapat digunakan dalam kehidupan bersama itu, baik oleh individu, golongan, asosiasi, maupun oleh Negara itu sendiri. 
mewarnai hubungan antara pemerintah pusat dan pemerintah daerah adalah mengenai pembagian kekuasaan serta alokasi sumber keuangan. ${ }^{2}$

Lahirnya UU No. 23/2014 sejatinya dimaksudkan sebagai penyempurnaan dan perbaikan dari undang-undang yang berlaku sebelumnya. Dalam UU No. 32/2004, Gubernur hanya memiliki 2 (dua) fungsi yaitu Gubernur sebagai kepala daerah otonom dan Gubernur sebagai wakil Pemerintah di daerah. Gubernur bertindak sebagai kepala daerah otonom yaitu manakala menjalankan kewenangan-kewenangan yang menjadi urusan wajib dan urusan pilihan pemerintah daerah provinsi (vide Pasal 13 UU No. 32/2004). Pembagian kewenangan sebagaimana diatur dalam Pasal 10, Pasal 13 dan Pasal 14 UU No. 32/2004 yang kemudian dijabarkan lebih lanjut dalam Peraturan Pemerintah Nomor 38 Tahun 2007 tentang Pembagian Urusan Pemerintahan antara Pemerintah, Pemerintahan Daerah Provinsi, dan Pemerintahan Daerah Kabupaten/Kota (PP No. 38/2007), dalam tataran praktik ternyata masih menimbulkan permasalahan, diantaranya seperti adanya overlapping kewenangan antara Pemerintah Provinsi dan Pemerintah Kabupaten/Kota, sering terjadinya miss komunikasi dan koordinasi antara Pemerintah Provinsi, Pemerintah Kabupaten/Kota, dan lain-lain.

Selanjutnya berkaitan dengan kewenangan Gubernur sebagai wakil pemerintah di daerah, dalam UU No. 32/2004 masih belum diatur secara tegas. Hal inilah yang kemudian dalam tataran praktik menimbulkan permasalahan, diantaranya yaitu tidak efektifnya pembinaan, pengawasan dan fungsi koordinasi yang dilakukan oleh Gubernur terhadap Bupati/Walikota dikarenakan ketidakjelasan tugas dan fungsi Gubernur dalam kapasitasnya sebagai wakil Pemerintah di daerah. Problematik kewenangan Gubernur sebagai wakil Pemerintah di daerah semakin parah ketika dilakukan pengkajian terhadap organ yang melakukan kewenangan tersebut. Bahwa tidak adanya pengaturan tentang organ yang membantu Gubernur, yang kemudian dalam prakteknya "terpaksa" diambil alih oleh Satuan Kerja Perangkat Daerah (SKPD), secara konsepsional

\footnotetext{
${ }^{2}$ Mexsasai Indra, Dinamika Hukum Tata Negara Indonesia, Refika Aditama, Bandung,
} 2011, h. 227. 
tidaklah tepat karena kewenangan Pemerintah dilakukan oleh organ pemerintah daerah.

Beranjak dari permasalahan-permasalahan yang muncul dalam UU No. 32/2004, maka lahirlah inisiatif untuk melakukan perubahan terhadap UU tersebut. Salah satu perubahan yang menarik untuk dicermati dalam UU No. 23/2014 adalah berkaitan dengan kedudukan gubernur dalam penyelenggaraan pemerintahan daerah di Indonesia. Berdasarkan Pasal 9, Pasal 10 Ayat (2), Pasal 11, Pasal 19 Ayat (1), Pasal 25 Ayat (2) UU No. 23/2014, dalam kaitannya dengan penyelenggaraan pemerintahan, Gubernur memiliki 3 (tiga) peran/fungsi yaitu Gubernur sebagai kepala daerah otonom, Gubernur sebagai wakil Pemerintah di daerah, dan Gubernur sebagai "wakil" Presiden dalam menyelenggarakan urusan pemerintahan umum.

Berkaitan dengan kewenangan Gubernur sebagai kepala daerah otonom yaitu terdiri dari urusan konkuren sebagaimana diatur dalam Pasal 11 dan Pasal 12 UU No. 23/2014. Pembagian kewenangan daerah otonom dalam UU ini tidak terlalu rigid sebagaimana diatur dalam UU No. 32/2004, karena senyatanya kewenangan disini bisa saling dibagi, baik dengan Pemerintah maupun Pemerintah Kabupaten/Kota, oleh karenanya nomenklatur yang digunakan tidak lagi urusan pemerintah provinsi dan urusan pemerintah kabupaten/kota, melainkan urusan konkuren yang terdiri dari urusan wajib dan urusan pilihan. Kewenangan ini merupakan konkretisasi dari fungsi desentralisasi yang dimiliki oleh Gubernur.

Gubernur bertindak sebagai wakil Pemerintah di daerah yaitu manakala Gubernur menjalankan urusan pemerintahan absolut yang menjadi kewenangan Pemerintah yang dilimpahkan kepadanya (Pasal 10 Ayat 2 huruf b UU No. 23/2014), meliputi politik luar negeri; pertahanan; keamanan; yustisi; moneter dan fiskal nasional; dan agama. Selanjutnya juga urusan konkuren yang menjadi kewenangan Pemerintah yang dilimpahkan kepadanya (vide Pasal 19 Ayat 2 huruf b UU No. 23/2014). Selain itu kewenangan lain Gubernur sebagai wakil Pemerintah yaitu berkaitan dengan pembinaan dan pengawasan terhadap penyelenggaraan Urusan Pemerintahan oleh Daerah kabupaten/kota (vide Pasal 8 
Ayat 2 UU No. 23/2014). Kewenangan ini merupakan konkretisasi dari fungsi dekonsentrasi.

Sedangkan Gubernur dikatakan bertindak sebagai "wakil” Presiden dalam menyelenggarakan urusan pemerintahan umum, yaitu manakala Gubernur menjalankan kewenangan sebagaimana diatur dalam Pasal 25 Ayat (1) UU No. 23/2014. Untuk melaksanakan urusan pemerintahan umum, Gubernur dapat dibantu oleh Instansi Vertikal. Dalam melaksanakan urusan pemerintahan umum, Gubernur bertanggung jawab kepada Presiden melalui Menteri dan Bupati/Walikota bertanggung jawab kepada Menteri melalui gubernur sebagai wakil Pemerintah Pusat. Berdasarkan latar belakang yang telah diuraikan diatas, maka isu yang menarik untuk dikaji yaitu mengenai fungsi Gubernur dalam penyelenggaraan pemerintahan di Indonesia .

\section{B. PEMBAHASAN}

Sejarah pertumbuhan pemerintahan daerah modern di Indonesia dapat dirunut mulai dari masa penjajahan Belanda sampai era reformasi dewasa ini. Sejak dikeluarkannya kebijakan desentralisasi yang pertama pada tahun 1903 dengan dikeluarkannya Decentralisatie Wet hingga kini, Indonesia telah mengalami beberapa fase pemerintahan daerah. Berdasarkan catatan penulis, dalam sekitar satu abad, Indonesia telah mengalami 8 (delapan) kali perubahan tata pemerintahan daerah yang ditandai dengan adanya 8 (delapan) peraturan perundang-undangan, belum termasuk yang hanya dilakukan sedikit perubahan. Dalam setiap peraturan perundang-undangan tersebut tentunya memiliki politik hukumnya sendiri. Secara singkat politik hukum masing-masing UU tersebut dapat dijelaskan dalam tabel berikut :

Tabel 1 : Perbandingan Pengaturan Hukum Pemerintahan Daerah

\begin{tabular}{|l|l|l|l|l|}
\hline Aspek Pembeda & $\begin{array}{l}\text { Sistem } \\
\text { Otonomi }\end{array}$ & $\begin{array}{l}\text { Hubungan } \\
\text { Pusat dan } \\
\text { Daerah }\end{array}$ & $\begin{array}{l}\text { Penyelenggara } \\
\text { Pemerintahan } \\
\text { Daerah }\end{array}$ & Pembagian Daerah \\
\cline { 1 - 4 } Undang-Undang & $\begin{array}{l}\text { Belum } \\
\text { jelas }\end{array}$ & Belum jelas & $\begin{array}{l}\text { Kepala daerah } \\
\text { bersama-sama } \\
\text { Komite }\end{array}$ & $\begin{array}{l}\text { - Ada 3 tingkatan : } \\
\text { Provinsi, Kabupat } \\
\text { en/Kota besar, }\end{array}$ \\
\hline
\end{tabular}




\begin{tabular}{|c|c|c|c|c|}
\hline & & & $\begin{array}{l}\text { Nasional } \\
\text { Daerah }\end{array}$ & $\begin{array}{l}\text { Desa/kota kecil. } \\
\text { - } \text { Belum ada } \\
\text { pengaturan } \\
\text { wilayah } \\
\text { administratif }\end{array}$ \\
\hline UU No. 22/1948 & $\begin{array}{l}\text { Otonomi } \\
\text { riil }\end{array}$ & $\begin{array}{l}\text { Berdasarkan } \\
\text { asas } \\
\text { desentralisasi } \\
\text { dan tugas } \\
\text { pembantuan }\end{array}$ & $\begin{array}{l}\text { Kepala Daerah, } \\
\text { Dewan } \\
\text { Pemerintah } \\
\text { Daerah, serta } \\
\text { Dewan } \\
\text { Perwakilan } \\
\text { Rakyat Daerah }\end{array}$ & 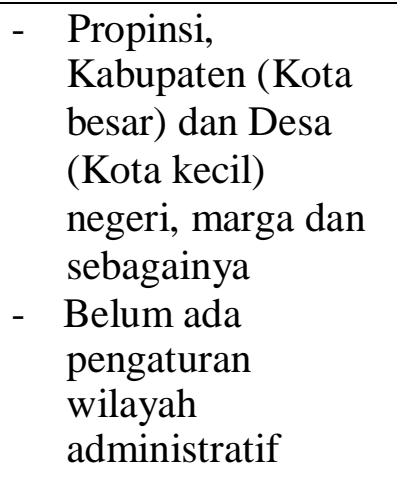 \\
\hline UU No. 1/1957 & $\begin{array}{l}\text { Otonomi } \\
\text { riil dan } \\
\text { seluas- } \\
\text { luasnya }\end{array}$ & $\begin{array}{l}\text { Mengatur asas } \\
\text { desentralisasi } \\
\text { dan tugas } \\
\text { pembantuan, } \\
\text { namun tidak } \\
\text { mengakomodir } \\
\text { asas } \\
\text { dekonsentrasi } \\
\text { dan } \\
\text { pemerintahan } \\
\text { pamong praja }\end{array}$ & $\begin{array}{l}\text { Kepala Daerah } \\
\text { sebagai Kepala } \\
\text { Pemerintahan } \\
\text { Dewan } \\
\text { Pemerintah } \\
\text { Daerah dan } \\
\text { Dewan } \\
\text { Perwakilan } \\
\text { Rakyat Daerah }\end{array}$ & $\begin{array}{l}\text { - Daerah otonom } \\
\text { disebut "Daerah } \\
\text { Swatantra". } \\
\text { Daerah Istimewa } \\
\text { disebut dengan } \\
\text { "Daerah } \\
\text { Swapraja", dan } \\
\text { daerah kota yang } \\
\text { mengatur rumah } \\
\text { tangganya sendiri } \\
\text { disebut } \\
\text { "Kotapraja" } \\
\text { - Tingkatan daerah } \\
\text { meliputi : Daerah } \\
\text { Tingkat ke I, } \\
\text { termasuk } \\
\text { Kotaparaja Jakarta } \\
\text { Raya, Daerah } \\
\text { Tingkat ke II, } \\
\text { termasuk } \\
\text { Kotapraja, dan } \\
\text { Daerah Tingkat ke } \\
\text { III. Begitu juga } \\
\text { dengan daerah } \\
\text { Swaparaja dibagi } \\
\text { atas daerah tingkat } \\
\text { ke I, daerah tingkat } \\
\text { ke II, dan daerah } \\
\text { tingkat ke III, } \\
\text { tingkatan yang } \\
\text { sama juga berlaku } \\
\text { untuk daerah }\end{array}$ \\
\hline
\end{tabular}




\begin{tabular}{|c|c|c|c|c|}
\hline & & & & $\begin{array}{l}\text { Swatantra (tapi } \\
\text { hanya sampai } \\
\text { daerah swatantra } \\
\text { tingkat ke II) } \\
\text { - } \\
\text { Tidak mengatur } \\
\text { daerah } \\
\text { administratif }\end{array}$ \\
\hline UU No. 18/1965 & $\begin{array}{l}\text { Otonomi } \\
\text { riil }\end{array}$ & $\begin{array}{l}\text { - } \text { Telah } \\
\text { mengakomodi } \\
\text { r adanya asas } \\
\text { desentralisasi, } \\
\text { dekonsentrasi, } \\
\text { maupun tugas } \\
\text { pembantuan } \\
\text { - Kepala } \\
\text { Daerah bukan } \\
\text { saja } \\
\text { merupakan } \\
\text { pimpinan } \\
\text { Pemerintah } \\
\text { Daerah, tetapi } \\
\text { juga } \\
\text { merupakan } \\
\text { alat } \\
\text { Pemerintah } \\
\text { Pusat }\end{array}$ & $\begin{array}{l}\text { Kepala Daerah } \\
\text { (dibantu oleh } \\
\text { Wakil Kepala } \\
\text { Daerah serta } \\
\text { Badan } \\
\text { Pemerintah } \\
\text { Harian) dan } \\
\text { Dewan } \\
\text { Perwakilan } \\
\text { Daerah }\end{array}$ & $\begin{array}{l}\text { Tingkatan daerah } \\
\text { meliputi : Propinsi } \\
\text { dan/atau Kotapraja } \\
\text { sebagai Daerah } \\
\text { tingkat I, Kabupaten } \\
\text { dan/atau Kotamadya } \\
\text { sebagai Daerah } \\
\text { tingkat II, dan } \\
\text { Kecamatan dan/atau } \\
\text { Kotapraja sebagai } \\
\text { Daerah tingkat III. }\end{array}$ \\
\hline UU No. 5/1974 & $\begin{array}{l}\text { Otonomi } \\
\text { nyata dan } \\
\text { bertanggu } \\
\text { ng jawab }\end{array}$ & $\begin{array}{l}\text { Menganut asas } \\
\text { desentralisasi, } \\
\text { dekonsentrasi } \\
\text { dan tugas } \\
\text { pembantuan. } \\
\text { Namun } \\
\text { penerapan asas } \\
\text { dekonsentrasi } \\
\text { lebih menonjol, } \\
\text { bahkan sistem } \\
\text { otonomi seakan- } \\
\text { akan tidak } \\
\text { berjalan karena } \\
\text { hampir semua } \\
\text { urusan diambil } \\
\text { alih oleh } \\
\text { Pemerintah. }\end{array}$ & $\begin{array}{l}\text { Kepala Daerah } \\
\text { dan DPRD }\end{array}$ & 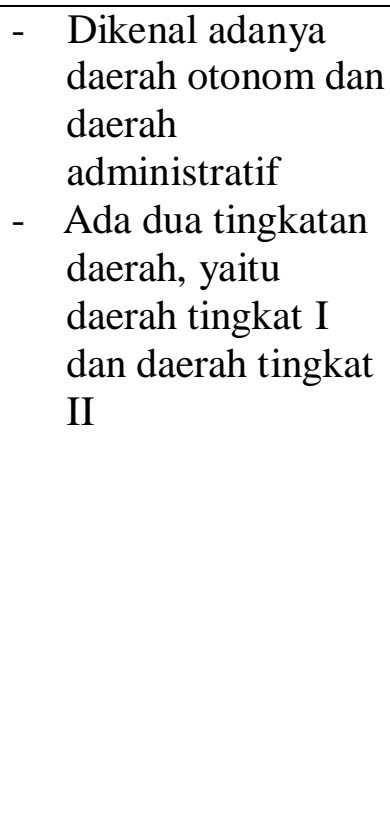 \\
\hline UU No. 22/1999 & $\begin{array}{l}\text { Otonomi } \\
\text { luas, nyata } \\
\text { dan } \\
\text { bertanggu }\end{array}$ & $\begin{array}{l}\text { - Menganut } \\
\text { asas } \\
\text { desentralisasi, } \\
\text { dekonsentrasi }\end{array}$ & $\begin{array}{l}\text { Pemerintah } \\
\text { Daerah } \\
\text { (Kepala } \\
\text { Daerah dan }\end{array}$ & $\begin{array}{l}\text { - } \text { Wilayah Negara } \\
\text { Kesatuan Republik } \\
\text { Indonesia dibagi } \\
\text { dalam Daerah }\end{array}$ \\
\hline
\end{tabular}




\begin{tabular}{|c|c|c|c|c|}
\hline & ng jawab & $\begin{array}{l}\text { dan tugas } \\
\text { pembantuan } \\
\text { - Tidak } \\
\text { mengenal } \\
\text { sistem } \\
\text { otonomi } \\
\text { bertingkat }\end{array}$ & $\begin{array}{l}\text { SKPD) } \\
\text { bersama-sama } \\
\text { DPRD }\end{array}$ & 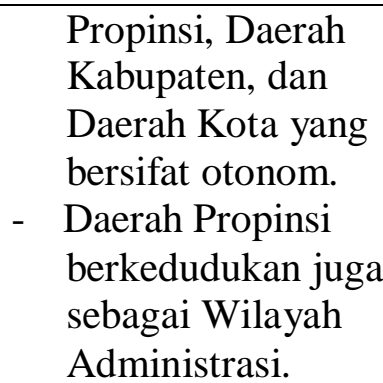 \\
\hline UU No. $32 / 2004$ & $\begin{array}{l}\text { Otonomi } \\
\text { seluas- } \\
\text { luasnya, } \\
\text { nyata dan } \\
\text { bertanggu } \\
\text { ng jawab }\end{array}$ & $\begin{array}{l}\text { Menganut asas } \\
\text { desentralisasi, } \\
\text { dekonsentrasi } \\
\text { dan tugas } \\
\text { pembantuan }\end{array}$ & $\begin{array}{l}\text { Pemerintah } \\
\text { Daerah } \\
\text { (Kepala } \\
\text { Daerah dan } \\
\text { SKPD) } \\
\text { bersama-sama } \\
\text { DPRD }\end{array}$ & $\begin{array}{ll}\text { - } & \text { Wilayah Negara } \\
\text { Kesatuan Republik } \\
\text { Indonesia dibagi } \\
\text { dalam Daerah } \\
\text { Propinsi, Daerah } \\
\text { Kabupaten, dan } \\
\text { Daerah Kota yang } \\
\text { bersifat otonom. } \\
\text { - } \\
\text { Daerah Propinsi } \\
\text { berkedudukan juga } \\
\text { sebagai Wilayah } \\
\text { Administrasi. }\end{array}$ \\
\hline UU No. $23 / 2014$ & $\begin{array}{l}\text { Otonomi } \\
\text { seluas- } \\
\text { luasnya, } \\
\text { nyata dan } \\
\text { bertanggu } \\
\text { ng jawab }\end{array}$ & $\begin{array}{l}\text { - Menganut } \\
\text { asas } \\
\text { desentralisasi, } \\
\text { dekonsentrasi } \\
\text { dan tugas } \\
\text { pembantuan } \\
\text { - Tampak } \\
\text { adanya } \\
\text { penguatan } \\
\text { fungsi } \\
\text { Gubernur } \\
\text { sebagai organ } \\
\text { pemerintah } \\
\text { pusat }\end{array}$ & $\begin{array}{l}\text { Kepala Daerah } \\
\text { dan DPRD }\end{array}$ & 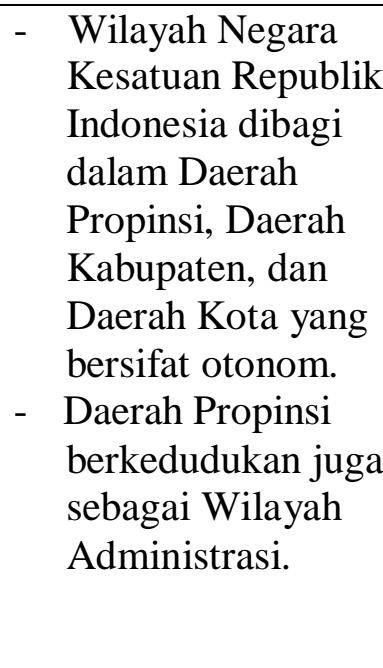 \\
\hline
\end{tabular}

Berdasarkan tabel tersebut, nampak bahwa sistem penyelenggaraan pemerintahan daerah di Indonesia sesungguhnya menerapkan asas desentralisasi, dekonsentrasi maupun tugas pembantuan. Dalam kaitannya dengan hal tersebut, Gubernur sebagai bagian dari penyelenggara pemerintahan memiliki 2 (dua) fungsi. yakni sebagai kepala daerah provinsi dan Wakil Pemerintah Pusat di Daerah, dalam pengertian untuk menjembatani dan memperpendek rentang kendali (span of control) pelaksanaan tugas dan fungsi pemerintahan, termasuk 
dalam pembinaan dan pengawasan terhadap penyelenggaraan urusan pemerintahan di daerah kabupaten dan kota. Dengan kata lain, Gubernur di satu sisi menjalankan fungsi desentralisasi, dan di sisi lain menjalankan fungsi dekonsentrasi. Namun dalam praktek, seringkali terjadi kerancuan diantara keduanya. Untuk menghilangkan kerancuan pemahaman terhadap desentralisasi dan dekonsentrasi, Mawhood menggambarkan dalam tabel berikut yang dapat digunakan sebagai acuan dalam membedakan pengertian yang terkandung dalam kedua peristilahan tersebut $:^{3}$

Tabel 2 : Perbandingan Dekonsentrasi dan Desentralisasi

\begin{tabular}{|c|c|c|}
\hline Pemakaian Istilah & Dekonsentrasi & Desentralisasi \\
\hline Prinsip Organisasi & $\begin{array}{l}\text { Dekonsentrasi } \\
\text { Dekonsentrasi } \\
\text { Desentralisasi Birokrasi } \\
\text { Desentralisasi } \\
\text { Administratif }\end{array}$ & $\begin{array}{l}\text { Desentralisasi } \\
\text { Devolusi } \\
\text { Desentralisasi } \\
\text { Demokratik } \\
\text { Desentralisasi Politik }\end{array}$ \\
\hline $\begin{array}{l}\text { Struktur dimana Prinsip } \\
\text { ini dipakai }\end{array}$ & $\begin{array}{l}\text { Administrasi Wilayah } \\
\text { Administrasi Regional } \\
\text { Administrasi Prefectur }\end{array}$ & $\begin{array}{l}\text { Pemerintah Daerah } \\
\text { Pemerintah Daerah } \\
\text { Pemerintah Kota }\end{array}$ \\
\hline Praktek & $\begin{array}{l}\text { Pendelegasian } \\
\text { Kekuasaan }\end{array}$ & Devolusi Kekuasaan \\
\hline
\end{tabular}

Dari tabel diatas tampak bahwa pemerintah daerah adalah manifestasi struktural dari kebijaksanaan desentralisasi, sedangkan pemerintah wilayah berawal dari dekonsentrasi. Setiap pemerintah suatu negara dapat membuat kebijakan yang lebih menekankan pada pemakaian pemerintah daerah atau pemerintah wilayah, tergantung dari justifikasi elit yang berkuasa. Umumnya pilihan akan dekonsentrasi didasarkan pada alasan apakah bentukan tersebut akan dapat berperan sama efektifnya dengan pemerintah daerah di dalam mengurangi tekanan-tekanan yang dialamatkan kepada pemerintah pusat dan juga sejauh mana bentukan ini dapat menjamin peningkatan pembangunan di daerah. ${ }^{4}$

Sebaliknya pilihan terhadap pemerintah daerah didasarkan pada argumen sejauhmana pemerintah daerah yang berbeda dengan kantor departemen yang ada

\footnotetext{
${ }^{3}$ Oentarto, SM, Menggagas Format Otonomi Daerah Masa Depan, Samitra Media Utama, Jakarta, 2004, h. 28.

${ }^{4}$ Suryo Sakti Hadiwijoyo, 2011, Gubernur : Kedudukan, Peran dan Kewenangannya, Graha Ilmu, Yogyakarta, h. 221.
} 
di wilayah dapat menyediakan pelayanan-pelayanan untuk memenuhi tuntutan masyarakat daerah secara lebih efisien. Umumnya perbedaannya akan terletak pada sejauhmana kemampuan untuk mengerti kebutuhan daerah dan permasalahannya serta tingkat tanggung jawabnya. Namun demikian, kedekatan pemerintah daerah dengan rakyat, baik secara geografis ataupun sosial, akan lebih memungkinkan pemerintah daerah lebih fleksibel dan akuntabel dengan kantorkantor perwakilan pusat (field administration) yang ada di daerah. ${ }^{5}$

\section{Implementasi Desentralisasi dan Fungsi Gubernur sebagai Kepala Daerah Otonom}

Berdasarkan Pasal 1 Angka 8 UU No. 23/2014, desentralisasi didefinisikan sebagai penyerahan urusan pemerintahan oleh Pemerintah Pusat kepada daerah otonom berdasarkan asas otonomi.

Pemaknaan asas desentralisasi sesungguhnya telah menjadi perdebatan yang tak kunjung usai di kalangan pakar dalam mengkaji dan melihat penerapan asas ini dalam pelaksanaan pemerintahan daerah. Perdebatan yang muncul diakibatkan oleh cara pandang dalam mengartikulasikan dari sisi mana desentralisasi diposisikan dalam pelaksanaan pemerintahan daerah. Dari pemaknaan asas desentralisasi para pakar dapat diklasifikasi dalam beberapa hal, diantaranya : (1) desentralisasi sebagai penyerahan kewenangan dan kekuasaan; (2) desentralisasi sebagai pelimpahan kekuasaan dan kewenangan; (3) desentralisasi sebagai pembagian, penyebaran, pemencaran, dan pemberian kekuasaan dan kewenangan, serta (4) desentralisasi sebagai sarana dalam pembagian dan pembentukan daerah pemerintahan.

Pertama, pandangan pakar yang menganggap bahwa desentralisasi merupakan penyerahan kekuasaan dan kewenangan dapat dilihat dari pandangan yang sama antara Hazairin ${ }^{6}$, Kartasapoetra ${ }^{7}, \mathrm{Koswara}^{8}$, Seligman ${ }^{9}$, dan Van den

\footnotetext{
${ }^{5} \mathrm{M}$ Bowman and W. Hampton, Local Democracies: A Study in Comparative Local Government ( Melbourne: Longman), 1983. Dikutip tidak langsung, dari Koirudin, Sketsa desentralisasi di Indonesia, Format Masa Depan Otonomi Menuju Kemandirian Daerah ( Malang: Averroes Press, 2005), h. 2.

${ }^{6}$ The Liang Gie, Pertumbuhan Pemerintahan Daerah di Negara Republik Indonesia, Liberty, Yogyakarta, 1967, h. 109. Menurut Hazairin, desentralisasi sebagai suatu cara pemerintahan dalam mana sebagian kekuasaan mengatur dan mengurus dari pemerintahan pusat
} 
Berg $^{10}$ yang menganggap bahwa desentralisasi sebagai penyerahan kekuasaan (urusan) pemerintah pusat kepada daerah. ${ }^{11}$ Sementara, De Ruiter ${ }^{12}$ berpandangan bahwa penyerahan kekuasaan atau wewenang ini terjadi bukan dari pemerintah pusat, tetapi dari badan yang lebih tinggi kepada badan yang lebih renah. Dalam arti ketatanegaraan, yang dimaksud dengan desentralisasi adalah penyerahan urusan pemerintahan dari pemerintah atau daerah tingkat atasnya kepada daerah untum menjadi urusan rumah tangganya. Pemaknaan seperti inilah yang kemudian diakomodir dalam UU No. 5/1974.

Pemaknaan desentralisasi dibedakan dalam 4 (empat) hal, yakni : (1) kewenangan untuk mengambil keputusan diserahkan dari seorang pejabat administrasi/pemerintah kepada yang lain; (2) pejabat yang menyerahkan itu mempunyai lingkungan pekerjaan yang lebih luas daripada pejabat yang diserahi

dierahkan kepada kekuasaan-kekuasaan bawahan sehingga daerah mempunyai pemerintahan sendiri.

${ }^{7}$ R. G. Kartasapoetra, Sistematika Hukum Tata Negara, Bina Aksara, Jakarta, 1987, h. 87 \& 98. Desentralisasi diartikan sebagai penyerahan urusan dari pemerintah pusat kepada daerah menjadi urusan rumah tangganya. Penyerahan urusan ini bertujuan untuk mencegah pemusatan kekuasaan, keuangan serta sebagai pendemokratisasian pemerintahan, untuk mengikutsertakan rakyat bertanggung jawab terhadap penyelenggaraan pemerintahan di daerah.

${ }^{8}$ E. Koswara, Otonomi Daerah : Untuk Demokrasi dan Kemandirian Rakyat, Yayasan PARIBA, Jakarta, 2001, h. 17. Desentralisasi adalah sebagai proses penyerahan urusan-urusan pemerintahan yang semula termasuk wewenang pemerintah pusat kepada badan atau lembaga pemerintahan daerah agar menjadi urusan rumah tangganya sehingga urusan tersebut beralih kepada dan menjadi tanggung jawab pemerintah daerah.

${ }^{9}$ Ermaya Suradinata, Kebijaksanaan Pembangunan dalam Pelaksanaan Otonomi Daerah, Ramadan, Bandung, 1993, h. 146. Seligman menyatakan bahwa desentralisasi merupakan suatu proses penyerahan wewenang dari pemerintahan yang lebih tinggi atau yang mempunyai kekuasaan kepada pemerintah yang lebih rendah derajatnya, menyangkut bidang legislatif, yudikatif atau administratif.

${ }^{10}$ Bagir Manan, Hubungan Antara Pusat dan Daerah Berdasarkan Asas Desentralisasi Menurut UUD 1945, Disertasi, UNPAD, Bandung 1990, h. 3 \& 15. Van den Burg melihat persoalan hubungan antara pusat dan daerah pada negara dengan susunan organisasi desentralistik timbul karena pelaksanaan wewenang, tugas dan tanggung jawab pemerintahan negara tidak hanya dilakukan oleh atau dari satu pusat pemerintahan, tetapi terdapat satuan pemerintahan lebih rendah yang juga melakukan wewennang, tugas dan tanggung jawab melaksanakan sebagian urusan pemerintahan yang diserahkan atau yang dibiarkan dan diakui sebagai urusan daerah bersangkutan.

${ }^{11}$ HM. Laica Marzuki, Berjalan-Jalan di Ranah Hukum, Sekjen dan Kepaniteraan Mahkamah Konstitusi RI, Jakarta, 2006, h. 151. Dalam makna ketatanegaraan, desentralisasi adalah penyerahan kekuasaan pusat kepada daerah-daerah. Desentralisasi merupakan staaskundege decentralisatie bukan ambtelijke decentralisatie seperti halnya dengan dekonsentrai.

${ }^{12}$ Ateng Syafrudin, Pasang Surut Otonomi Daerah, Bina Cipta, Bandung, 1985, h. 4. Menurut De Ruiter, deentralisasi sebagai pengakuan dan penyerahan wewenang oleh badan-badan umum yang lebih tinggi kepada badan-badan umum yang lebih rendah untuk secara mandiri dan berdasarkan pertimbangan kepentingan sendiri mengambil keputusan pengaturan dan pemerintahan serta struktur wewenang yang terjadi dalam hal itu. 
kewenangan; (3) pejabat yang menyerahkan kewenangan tidak dapat memberi perintah kepada pejabat yang telah diserahi kewenangan itu, mengenai pengambilan keputusan atau isi keputusan itu; serta (4) pejabat yang menyerahkan kewenangan itu tidak dapat menjadikan keputusannya sendiri sebagai pengganti keputusan yang telah diambil, tidak dapat secara bebas menurut pilihan sendiri sebagai pengganti keputusan yang telah diserahi kewenangan itu dengan orang lain, tidak dapat menyingkirkan pejabat yang telah diserahi kewenangan itu dari tempatnya. $^{13}$

Kedua, pandangan pakar yang menganggap bahwa desentralisasi merupakan pelimpahan kekuasaan dan kewenangan dapat dilihat dari pandangan Logemann ${ }^{14}$ dan Litvack ${ }^{15}$ bahwa desentralisasi adalah sebagai pelimpahan kewenangan dari pusat ke daerah, tetapi Litvack lebih jauh memaknai pelimpahan karena juga bisa kepada sektor swasta.

Salah satu permasalahan yang mendasar adalah pendelegasian kewenangan kepada pemerintah daerah serta seberapa besar kewenangan yang dilimpahkan atau diserahkan kepada daerah dalam mengurus dan mengatur pelaksanaan pemerintahan di daerah. ${ }^{16}$ Diferensiasi masalah yang begitu kompleks di daerah tidak mungkin diurus/ditangani semua oleh pemerintahan di pusat. Untuk

\footnotetext{
${ }^{13}$ Agussalim Andi Gadjong, Pemerintahan Daerah : Kajian Politik dan Hukum, Penerbit Ghalia Indonesia, Bogor, 2007, h. 81.

${ }^{14}$ The Liang Gie, Pertumbuhan Pemerintahan Daerah di Negara Republik Indonesia, Gunung Agung, Jakarta, 1967, h. 10. Menurut Logemann, desentralisasi sebagai pelimpahan kekuasaan dari penguasa negara kepada persekutuan-persekutuan yang berpemerintahan sendiri. Lebih lanjut beliau menyatakan di desentaralisasi meliputi dekonsentrasi atau ambtelijke decentralisatie yang dimaksudkan adalah rakyat tidak diikutsertakan dalam pelimpahan kekuasaan dan kewenangan. Sedangkan desentralisasi kenegaraan atau staaskundige decentralisatie atau desentralisasi publik yaitu pelimpahan kekuasan perundangan dan pemerintahan atau regelenden besturende bevogheid kepada daerah-daerah otonom di dalam lingkungannya. Disini masyarakat diikutsertakan dalam pemerintahan dengan mempergunakan saluran tertentu yaitu perwakilan rakyat sesuai batas wilayah administratif yang telah ditentukan.

${ }^{15}$ Litvack, Jennie, Juaid Ahmda, Richard Bird, Indonesia: DecentralizationOpportunities and Risks. IMF and World Bank Resident Mission., h. 7.

${ }^{16}$ Sodjuangon Situmorang, Model Pembagian Urusan Pemerintahan Antara Pemerintah, Provinsi dan Kabupaten/Kota, Disertasi, FISIP PPS UI, Jakarta, 2002, h. 1. Pendapat Muhammad Hatta banyaknya masalah mengenai pelaksanaan pemerintahan di daerah, tentunya semuanya tidak dapat diurus pemerintah pusat, maka harus dilakukan pembagian kekuasaan atau tugas antara pemerintah daerah yang mengurus kepentingan di daerah-daerah, dan kepentingan daerah yang lebih luas dan negara seluruhnya diurus oleh pemerintahan lingkungannya yang lebih luas dan oleh pemerintah pusat. Hatta menyatakan bahwa sentralisasi akan memperkuat sistem birokrasi dan melemahkan, jika tidak melenyapkan kontrol rakyat atas pemerintah dan DPR. Masalah yang sulit adalah bagaimana membagi tugas (kekuasaan antara pusat dan daerah).
} 
menjembatani hal ini, maka titik pemecahannya yaitu melalui pembagian kekuasaan atau kewenangan antara pemerintah pusat dengan pemerintahan di daerah-daerah.

Ketiga, pandangan pakar yang menganggap bahwa desentralisasi dalam sistem pemerintahan merupakan pembagian, penyebaran, pemencaran, pemberian kekuasaan, dan kewenangan dapat dilihat dari pandangan yang dikemukakan oleh Duchacek $^{17}$, Maryanov ${ }^{18}$, dan Mawhood, bahwa masalah desentralisasi berujung pada pembagian kekuasaan atau kewenangan dalam suatu pemerintahan. ${ }^{19}$ Sementara, Hofman memberi istilah administrative decentralization, yang merupakan langkah dalam menyebarkan kewenangan untuk menjalankan urusanurusan pemerintahan, yang pada masa lalu disentralisasikan atau dipusatkan pada pemerintah pusat. $^{20}$

Di sisi lain, Tresna berpandangan bahwa desentralisasi diartikan sebagai pemberian kekuasaan mengatur diri kepada daerah-daerah dalam lingkungannya guna mewujudkan asas demokrasi, di dalam pemerintahan negara. ${ }^{21}$ Sedangkan Soehino $^{22}$ berpandangan bahwa, desentralisasi kedaerahan memberi wewenang kepada alat perlengkapan suatu lembaga hokum untuk membentuk aturan hukum in-abstracto dan pemberian delegasi kepada alat perlengkapan dari lembaga hukum public untuk membentuk aturan hukum in-concreto. Lain dengan

${ }^{17}$ BC. Smith, Decentralization : The Territorial Dimension of The State, Asia Publishing House, London, 1985. Desentralisasi berkenaan dengan pembagian kekuasaan atau kewenangan (urusan) pemerintahan antara berbagai tingkatan pemerintahan menyangkut hubungan saling ketergantungan antara pemerintah pusat dengan pemerintah daerah, yang melibatkan sarana, institusi, dan prosedur yang kompleks.

${ }^{18}$ Gerald S. Maryanov, Decentralization in Indonesia as a Political Problem, Interim Report Series Modern Indonesia Project, South-East Asia Program, Department of Far Eastern Studies, New York, Cornel University, Ithaca, 1958, h. 58. Maryanov mengatakan bahwa pembagian kekuasaan atau kewenangan (urusan) antara pusat dan daerah : "The Predominant symbol of demand in regard to the constitution of the affairs of a region is need for a division of authority between central government and regions. Whatever scheme is proposed for setting the division, one tentative suggestion can be made. By the authority that is to be divided is implied a set of ongoing (function) which must be performed by government. The question at hand is what organizational arrangement must be made for performing them-region or center."

${ }^{19}$ Philip Mawhood (ed), Local Government in The Third World : The Experience of Tropical Africa, Wiley, Chichecter, London-UK, 1983, h. 4.

${ }^{20}$ Bert Hofman, Indonesia: Decentralization- Opportunities and Risks, IMF and World Bank Resident Mission, 2000, h. 327. 31.

${ }^{21}$ R. Tresna, Bertamasya Ke Taman Ketatanegaraan, Dibya, Bandung, Tanpa Tahun, h.

\footnotetext{
${ }^{22}$ Soehino, Asas-Asas Hukum Tata Pemerintahan, Liberty, Yogyakarta, 1984, h. 183-184.
} 
Mustamin yang memaparkan bahwa desentralisasi berarti pemencaran atau penyebaran wewenang dari pusat ke bagian-bagian organisasi di bawahnya, baik secara territorial, fungsional, teknis maupun kultural. ${ }^{23}$

Keempat, pandangan pakar yang menganggap bahwa desentralisasi merupakan sarana dalam pembagian dan pembentukan daerah dapat dilihat dari pandangan Aldelfer ${ }^{24}$, yaitu desentralisasi adalah pembentukan daerah otonom dengan kekuasaan-kekuasaan tertentu dan bidang-bidang kegiatan tertentu yang diselenggarakan berdasarkan pertimbangan, inisiatif, dan administrasi sendiri. Jadi, desentralisasi menyangkut pembentukan daerah otonom dengan dilengkapi kewenangan-kewenangan tertentu dan bidang-bidang kegiatan tertentu.

Dari beberapa pandangan pakar di atas, dengan jelas menafsirkan bahwa dimensi desentralisasi melahirkan sisi penyerahan kewenangan, pembagian kekuasaan, pendelegasian kewenangan, dan pembagian daerah dalam struktur pemerintahan di negara kesatuan. Penyerahan, pendelegasian dan pembagian kewenangan dengan sendirinya menciptakan kewenangan pada pemerintah daerah dalam pelaksanaan pemerintahan di daerah, yang didahului pembagian daerah pemerintahan dalam bingkai daerah otonom.

Setelah memahami dimensi makna desentralisasi, maka dalam kaitanya dengan penyelenggaraan pemerintahan daerah, maka Kepala Daerah mempunyai peran penting untuk menjalankan fungsi tersebut. Gubernur sebagai Kepala Daerah Otonom di daerah Provinsi memiliki tugas dan wewenang menjalankan fungsi desentralisasi yang tercermin dalam urusan-urusan yang dilimpahkan kepada Pemerintah Daerah Provinsi berdasarkan peraturan perundang-undangan. Beberapa contoh tersebut diantaranya seperti pembentukan peraturan daerah, memungut pajak daerah yang menjadi kewenangan daerah provinsi, menerbitkan izin tertentu yang menjadi kewenangan daerah provinsi, dan lain-lain.

\footnotetext{
${ }^{23}$ Mustamin Dg Matutu, dkk., Mandat, Delegasi, Atribusi, dan Implementasinya di Indonesia, UII Press, Yogyakarta, 2004, h. 35-36.

${ }^{24}$ Aldelfer, Op. Cit., h. 176.
} 
Implementasi Dekonsentrasi dan Fungsi Gubernur sebagai Wakil Pemerintah Pusat

Istilah dekonsentrasi pertama kali disebutkan dalam UU No. 18/1965. Dalam UU No. 18/1965, definisi dekonsentrasi belum disebutkan secara jelas, namun hanya disinggung dalam bagian Penjelasan. Kemudian dalam UU No. 5/1974, dekonsentrasi barulah didefinisikan, yaitu dalam Pasal 1 huruf $\mathrm{f}$ disebutkan bahwa Dekonsentrasi adalah pelimpahan wewenang dari Pemerintah atau Kepala Wilayah atau Kepala Instansi Vertikal tingkat atasnya kepada Pejabat -pejabat di daerah. Sedangkan pengertian dekonsentrasi menurut UU No. 22/1999 adalah pelimpahan wewenang dari Pemerintah kepada Gubernur sebagai wakil Pemerintah dan atau perangkat pusat di Daerah (vide Pasal 1 huruf f). Selanjutnya dalam UU No. 32/2004, dekonsentrasi didefinisikan sebagai pelimpahan wewenang pemerintahan oleh Pemerintah kepada Gubernur sebagai wakil pemerintah dan/atau kepada instansi vertikal di wilayah tertentu (vide Pasal 1 Angka 8). Dan terakhir, dalam UU No. 23/2014, disebutkan bahwa dekonsentrasi adalah pelimpahan sebagian Urusan Pemerintahan yang menjadi kewenangan Pemerintah Pusat kepada gubernur sebagai wakil Pemerintah Pusat, kepada instansi vertikal di wilayah tertentu, dan/atau kepada gubernur dan bupati/wali kota sebagai penanggung jawab urusan pemerintahan umum (vide Pasal 1 Angka 9).

Menurut UU No. 32/2004, asas dekonsentrasi diselenggarakan melalui 2 (dua) cara, yaitu pertama, pelimpahan kewenangan Pemerintah kepada Perangkat Pusat di daerah; kedua, pelimpahan kewenangan Pemerintah kepada Gubernur sebagai Wakil Pemerintah di daerah. Pengaturan peyelenggaraan dekonsentrasi ini kemudian dijabarkan lebih lanjut dalam Peraturan Pemerintah Nomor 7 Tahun 2008 tentang Dekonsentrasi dan Tugas Pembantuan (PP No. 7/2008).

Sedangkan menurut UU No. 23/2014, pemaknaan dekonsentrasi diperluas. Pertama, yaitu pelimpahan kewenangan Pemerintah kepada Gubernur selaku wakil pemerintah pusat. Kedua, pelimpahan kewenangan Pemerintah kepada instansi vertikal di wilayah tertentu. Dan ketiga, pelimpahan kewenangan Pemerintah kepada gubernur dan bupati/walikota sebagai penanggung jawab urusan pemerintahan umum. Peraturan lebih lanjut mengenai dekonsentrasi 
berdasarkan UU No. 23/2014 masih merujuk pada PP No. 7/2008 sepanjang tidak bertentangan dengan prinsip-prinsip yang ada dalam UU No. 23/2014.

Masih berkaitan dengan pengertian dan definisi dekonsentrasi, Walfers menyatakan bahwa dekonsentrasi adalah pelimpahan wewenang pada pejabat atau kelompok pejabat yang diangkat oleh pemerintah pusat dalam wilayah administrasi. $^{25}$ Sedangkan dekonsentrasi menurut Henry Maddick sebagaimana dikutip oleh Bhenyamin Hoessein adalah pelimpahan wewenang untuk melepaskan fungsi-fungsi tertentu kepada pejabat pusat yang berada di luar kantor pusatnya. Oleh karena itu dekonsentrasi menciptakan local state government atau field administration. ${ }^{26}$

Dalam implementasinya menurut Smith, dekonsentrasi mempunyai ciri-ciri sebagai berikut $:^{27}$

(1) Pelimpahan wewenang untuk melaksanakan fungsi-fungsi tertentu yang dirinci dari Pemerintah Pusat kepada pejabat pemerintah pusat di daerah.

(2) Penerima wewenang adalah pejabat pemerintah pusat di daerah.

(3) Tidak mencakup kewenangan untuk menetapkan kebijakan dan wewenang untuk mengatur.

(4) Tidak menciptakan otonomi dan daerah otonom, tetapi menciptakan wilayah administratif.

(5) Keberadaan field administration berada dalam hierarki pemerintah pusat.

(6) Menunjukkan pola hubungan kekuasaan intraorganisasi.

(7) Menciptakan keseragaman dalam struktur politik.

Dekonsentrasi diberlakukan karena tidak semua wewenang dan tugas pemerintahan dapat dilaksanakan dengan menggunakan asas desentralisasi. Di samping itu, sebagai konsekuensi negara kesatuan memang tidak dimungkinkan semua wewenang pemerintah didesentralisasikan dan diotonomkan sekalipun kepada daerah.

Dalam asas dekonsentrasi terkandung beberapa prinsip dasar sebagai berikut: ${ }^{28}$

${ }^{25}$ Larmours and Qalo (Ed), Decentralization in The South Pacific, Papua New Guinea : University of The South Pacific, 1985.

${ }^{26}$ Bhenyamin Hoessein, Hubungan Penyelenggaraan Pemerintahan Pusat dengan Pemerintahan Daerah, Jurnal Bisnis dan Birokrasi No. 1///2000, h. 10.

${ }^{27}$ Smith, BC., Decentralization : The Territorial Dimension of State, George Allen and Urwin, Hemstead, 1985. 
(1) Merupakan manifestasi dari penyelenggaraan Pemerintahan Negara yang mempergunakan asas sentralisasi yang dipersempit atau diperluas.

(2) Merupakan asas yang bermaksud melakukan pelimpahan wewenang dari Pemerintah kepada Gubernur sebagai alat perlengkapan pemerintah pusat.

(3) Menimbulkan wilayah-wilayah administratif, yakni wilayah kerja Gubernur selaku Wakil Pemerintah.

(4) Merupakan manifestasi penyelenggaraan tata laksana Pemerintahan Umum Pusat yang ada di daerah.

(5) Dalam pelaksanaannya, asas dekonsentrasi tidak mengakibatkan adanya kewenangan dari suatu wilayah/organ pemerintahan untuk menentukan sendiri kebijaksanaan-kebijaksanaan, atau dengan kata lain tidak memiliki otonomi. Kewenangan, pendananaan, sarana dan prasarana semuanya ditentukan oleh Pemerintah Pusat.

Pada dasarnya dekonsentrasi masih dalam rumpun sentralisasi, dimana pemerintah pusat menugaskan aparatnya untuk menjalankan kewenangan pusat di daerah. Menurut Smith, unit pemerintah yag dibentuk dengan kebijakan dekonsentrasi tersebut disebut dengan "Field Administration".

Berdasarkan tataran teoretis tersebut terdapat beberapa ciri yang menonjol dari kebijakan dekonsentrasi, yaitu :

(1) Dekonsentrasi tidak lebih dari perpanjangan tangan pusat yang dilaksanakan di daerah melalui pejabat-pejabat pusat yang ditugaskan di daerah yang bersangkutan.

(2) Pejabat yang ditugaskan mempertanggungjawabkan pelaksanaannya ke pusat dan bukan kepada rakyat di daerah tersebut. Manakala kebijakan pusat tidak cocok untuk daerah, pejabat dekonsentrasi tersebut tidak mempunyai diskresi untuk mengubah kebijakan tersebut, namun hanya mnegusulkan perubahannya ke pusat. Rakyat tidak dapat meminta pertanggungjawaban perihal kebijkaan yang telah digariskan pusat. Pejabat dekonsentrasi hanya bertanggungjawab dari aspek pelaksanaan dari kebijakan tersebut.

(3) Kebijakan, jenis kegiatan, sasaran, biaya, sarana dan prasarana pelaksanaan tugas tersebut disiapkan oleh pusat. Anggaran pejabat

\footnotetext{
${ }^{28}$ Suryo Sakti Hadiwijoyo, Op. Cit., h. 217.
} 
dekonsentrasi berasal dari pusat, sehingga akuntabilitas pemanfaatan anggaran adalah ke pusat dan bukan ke rakyat daerah.

Batasan tentang dekonsentrasi menurut undang-undang sebagaimana disebutkan sebelumnya, mengandung beberapa persamaan sekaligus perbedaan yang sangat mendasar. Perbedaan-perbedaan tersebut sejalan dengan perubahan paradigma penyelenggaraan pemerintahan daerah, dari yang bersifat sentralistik kea arah desentralistik. Perbandingan pengertian dekonsentrasi menurut keempat undang-undang tersebut dapat dideskripsikan sebagaimana tabel sebagai berikut.

Tabel 3 : Perbandingan Pola Pelimpahan Kewenangan Dekonsentrasi Berdasarkan UU No. 5/1974, UU No. 22/1999, UU No. 32/2004, dan UU No. 23/2014

\begin{tabular}{|c|c|c|c|c|c|}
\hline No & $\begin{array}{c}\text { Aspek yang } \\
\text { diperbandingkan }\end{array}$ & $\begin{array}{l}\text { UU No. } \\
5 / 1974\end{array}$ & $\begin{array}{l}\text { UU No. } \\
\text { 22/1999 }\end{array}$ & $\begin{array}{l}\text { UU No. } \\
\text { 32/2004 }\end{array}$ & $\begin{array}{l}\text { UU No. } \\
\text { 23/2014 }\end{array}$ \\
\hline 1. & $\begin{array}{l}\text { Pola Alih } \\
\text { Kewenangan }\end{array}$ & $\begin{array}{l}\text { Pelimpahan } \\
\text { kewenangan }\end{array}$ & $\begin{array}{l}\text { Pelimpahan } \\
\text { kewenangan }\end{array}$ & $\begin{array}{l}\text { Pelimpahan } \\
\text { kewenangan }\end{array}$ & $\begin{array}{l}\text { Pelimpahan } \\
\text { kewenangan }\end{array}$ \\
\hline 2. & $\begin{array}{l}\text { Pemberi } \\
\text { pelimpahan } \\
\text { kewenangan }\end{array}$ & $\begin{array}{l}\text { Pemerintah } \\
\text { atau Kepala } \\
\text { Wilayah } \\
\text { (Gubernur/ } \\
\text { Bupati/ } \\
\text { Walikota/ } \\
\text { Camat) atau } \\
\text { Kepala } \\
\text { Instansi } \\
\text { Vertikal } \\
\text { tingkat } \\
\text { atasnya }\end{array}$ & $\begin{array}{l}\text { Pemerintah } \\
\text { Pusat }\end{array}$ & $\begin{array}{l}\text { Pemerintah } \\
\text { Pusat }\end{array}$ & $\begin{array}{l}\text { Pemerintah } \\
\text { Pusat }\end{array}$ \\
\hline 3. & $\begin{array}{l}\text { Pejabat penerima } \\
\text { pelimpahan } \\
\text { kewenangan }\end{array}$ & $\begin{array}{l}\text { - Kepala } \\
\text { Wilayah di } \\
\text { bawahnya } \\
\text { - Pejabat } \\
\text { Pemerintah } \\
\text { Pusat di } \\
\text { daerah }\end{array}$ & $\begin{array}{l}\text { - Gubernur } \\
\text { sebagai } \\
\text { wakil } \\
\text { pemerintah } \\
\text { pusat } \\
\text { - Perangkat } \\
\text { pusat di } \\
\text { daerah }\end{array}$ & $\begin{array}{l}\text { - Gubernur } \\
\text { sebagai } \\
\text { wakil } \\
\text { pemerintah } \\
\text { pusat } \\
\text { - Instansi } \\
\text { vertikal di } \\
\text { daerah }\end{array}$ & $\begin{array}{l}\text { - Gubernur } \\
\text { sebagai } \\
\text { wakil } \\
\text { pemerintah } \\
\text { pusat } \\
\text { - Instansi } \\
\text { vertikal di } \\
\text { daerah } \\
\text { - Gubernur } \\
\text { dan bupati/ } \\
\text { walikota } \\
\text { sebagai } \\
\text { penanggung } \\
\text { jawab } \\
\text { urusan }\end{array}$ \\
\hline
\end{tabular}




\begin{tabular}{|c|c|c|c|c|c|}
\hline & & & & & $\begin{array}{l}\text { pemerintaha } \\
\text { n umum }\end{array}$ \\
\hline 4. & Unit pelaksana & $\begin{array}{l}\text { Organisasi } \\
\text { Pemerintah } \\
\text { Wilayah } \\
\text { Instansi } \\
\text { Vertikal di } \\
\text { daerah }\end{array}$ & $\begin{array}{l}\text { Dinas } \\
\text { Provinsi } \\
\text { atau } \\
\text { Perangkat } \\
\text { Daerah } \\
\text { lainnya atau } \\
\text { Unit } \\
\text { Pelaksana } \\
\text { Khusus }\end{array}$ & $\begin{array}{l}\text { Dinas } \\
\text { Provinsi } \\
\text { atau } \\
\text { Perangkat } \\
\text { Daerah } \\
\text { lainnya atau } \\
\text { Unit } \\
\text { Pelaksana } \\
\text { Khusus }\end{array}$ & $\begin{array}{l}\text { Perangkat } \\
\text { Gubernur }\end{array}$ \\
\hline 5. & $\begin{array}{l}\text { Dasar hukum } \\
\text { untuk } \\
\text { melimpahkan }\end{array}$ & $\begin{array}{l}\text { Surat } \\
\text { Keputusan } \\
\text { dari masing- } \\
\text { masing } \\
\text { Pejabat yang } \\
\text { melimpahkan } \\
\text { kewenangan }\end{array}$ & $\begin{array}{l}\text { Keputusan } \\
\text { Presiden }\end{array}$ & $\begin{array}{l}\text { Peraturan } \\
\text { Pemerintah }\end{array}$ & $\begin{array}{l}\text { Peraturan } \\
\text { Pemerintah }\end{array}$ \\
\hline 6. & $\begin{array}{l}\text { Sumber } \\
\text { pembiayaan }\end{array}$ & APBN & APBN & APBN & APBN \\
\hline 7. & $\begin{array}{l}\text { Pengelolaan } \\
\text { anggaran }\end{array}$ & $\begin{array}{l}\text { Dibukukan } \\
\text { dalam APBD } \\
\text { masing- } \\
\text { masing }\end{array}$ & $\begin{array}{l}\text { Dibukukan } \\
\text { secara } \\
\text { terpisah }\end{array}$ & $\begin{array}{l}\text { Dibukukan } \\
\text { secara } \\
\text { terpisah }\end{array}$ & $\begin{array}{l}\text { Dibukukan } \\
\text { secara } \\
\text { terpisah }\end{array}$ \\
\hline
\end{tabular}

Berdasarkan tabel tersebut, ada 3 (tiga) aspek yang menarik untuk dikaji lebih lanjut dalam kaitannya dengan implementasi dekonsentrasi, yaitu mengenai unit pelaksana, dasar hukum untuk melimpahkan, dan model pelimpahan kewenangan. Unit pelaksana berkaitan dengan organ/pejabat mana yang berwenang menyelenggarakan tugas-tugas dekonsentrasi yang dilimpahkan kepada daerah. Dasar hukum untuk melimpahkan berkaitan dengan figur hukum yang digunakan sebagai landasan yuridis bagi pemerintah dalam melegitimasi pelimpahan kewenangan tersebut. Sedangkan model pelimpahan kewenangan terkait erat dengan pejabat mana yang dibebani pertanggungjawaban dalam penyelenggaraan tugas dekonsentrasi, yang mana secara rinci akan dianalisa lebih lanjut dalam Bab III.

Pertama, yaitu mengenai Unit Pelaksana. Adanya kejelasan lembaga/perangkat penyelenggara fungsi dekonsentrasi menjadi prasyarat penting yang harus diperhatikan. Terlebih, sejak lahirnya UU No. 22/1999, perangkat 
dekonsentrasi berupa kantor wilayah menjadi hapus, kecuali perangkat yang melaksanakan lima urusan absolut pemerintah pusat. Dampaknya, urusan dekonsentrasi "dititipkan" kepada perangkat desentralisasi, yakni dinas dan lembaga teknis daerah. Merujuk pada UU No. 22/1999 maupun UU No. 32/2004, disebutkan bahwa unit pelaksana tugas dekonsentrasi adalah Dinas Provinsi atau Perangkat Daerah lainnya atau Unit Pelaksana Khusus. Lebih lanjut dalam PP No. 7/2008 disebutkan bahwa sebagian urusan pemerintahan yang dilimpahkan kepada gubernur sebagai wakil pemerintah dilaksanakan oleh SKPD provinsi berdasarkan penetapan dari gubernur (Dinas merupakan salah satu SKPD, penulis). Menurut hemat penulis, hal ini tidaklah tepat mengingat Dinas adalah bagian dari organ pemerintahan daerah yang sumber pendanaannya dibebankan pada APBD. Jika merujuk pada Pasal 124 UU No. 32/2004, dengan jelas disebutkan bahwa Dinas daerah merupakan unsur pelaksana otonomi daerah. Dinas daerah dipimpin oleh kepala dinas yang diangkat dan diberhentikan oleh kepala daerah dari pegawai negeri sipil yang memenuhi syarat atas usul Sekretaris Daerah. Kepala dinas daerah bertanggung jawab kepada kepala daerah melalui Sekretaris Daerah. Dengan demikian, dalam kaitannya dengan pelaksanaan tugas dekonsentrasi maka tidaklah tepat jika pelaksanaannya oleh Dinas Provinsi atau Perangkat Daerah lainnya atau Unit Pelaksana Khusus yang notabene merupakan perangkat daerah yang kewenangannya adalah menyelenggarakan tugas desentralisasi. Selain kurang efektif, hal ini juga membuka kemungkinan terjadinya overlap (tumpang tindih) atau duplikasi tugas desentralisasi dan tugas dekonsentrasi. Adanya kerancuan seperti ini dalam prakteknya tentu menimbulkan beberapa permasalahan. Oleh karenanya, penataan kelembagaan dekonsentrasi menjadi salah satu kebutuhan mendesak dalam rangka mewadahi fungsi-fungsi yang dilimpahkan dari pemerintah pusat di daerah. Melihat adanya kelemahan tersebut, maka dengan diundangkannya UU No. 23/2014, maka dilakukanlah penyempurnaan terhadap keberadaan lembaga dekonsentrasi. Berdasarkan Pasal 93 disebutkan bahwa Gubernur dalam menyelenggarakan tugas sebagai wakil Pemerintah Pusat dibantu oleh perangkat gubernur, yang terdiri atas sekretariat dan paling banyak 5 (lima) unit kerja. Kemudian, disebutkan pula bahwa ketentuan lebih lanjut mengenai susunan organisasi, tugas, dan fungsi 
perangkat gubernur diatur dalam peraturan pemerintah. Namun hingga saat ini, peraturan pemerintah tersebut belum dibentuk.

Kedua, yaitu dasar hukum untuk melakukan pelimpahan. Berdasarkan UU No. 5/1974, figur hukum yang digunakan dalam rangka pelimpahan tugas dekonsentrasi adalah Surat Keputusan dari masing-masing Pejabat yang melimpahkan kewenangan. Kemudian dalam UU No. 22/1999, figur hukum yang digunakan adalah Keputusan Presiden. Dalam UU No. 32/2004, pelimpahan tugas dekonsentrasi menggunakan figur hukum Peraturan Pemerintah, yang kemudian ditindaklanjuti dengan PP No. 38/2007. Hal itu dapat dilihat dalam Pasal 14 Ayat (3). Selanjutnya dalam Pasal 4 Ayat (2) PP No. 38/2007, disebutkan bahwa "Ketentuan lebih lanjut mengenai pengaturan teknis untuk masing-masing sub bidang atau sub sub bidang urusan pemerintahan diatur dengan peraturan menteri/kepala lembaga pemerintahan non departemen yang membidangi urusan pemerintahan yang bersangkutan setelah berkoordinasi dengan Menteri Dalam Negeri." Artinya, manakala terdapat tugas dekonsentrasi yang dilimpahkan oleh Pemerintah, maka dasar hukum yang digunakan adalah dalam bentuk peraturan menteri/kepala lembaga pemerintahan non departemen yang membidangi urusan pemerintahan yang bersangkutan. Sebagai contoh di Provinsi Jawa Timur. Salah satu urusan pemerintahan yang didekonsentrasikan yaitu mengenai pengelolaan bandara Abdulrachman Saleh di Malang berdasarkan Keputusan Menteri Perhubungan Nomor KP 502 Tahun 2011 tentang Pengoperasian Bandar Udara Abdulrahman Saleh Malang Provinsi Jawa Timur Untuk Penerbangan Sipil. Berkenaan dengan hal tersebut, Pemerintah Daerah Provinsi Jawa Timur telah menerima pelimpahan tugas dari Menteri Perhubungan untuk mengoperasikan Bandar Udara Abdulrahman Saleh Malang sebagai bandara untuk penerbangan sipil dalam rangka melakukan pelayanan publik di bidang transportasi udara serta memenuhi kebutuhan masyarakat akan pelayanan angkutan udara. Demi tercapainya tujuan tersebut serta untuk mendorong pertumbuhan ekonomi daerah maka Pemerintah Daerah Provinsi menetapkan kebijakan sebagai dasar hukum bagi Unit Penyelenggara Bandar Udara dalam melaksanakan kewenangan untuk menyelenggarakan dan mengelola Bandar Udara Abdulrachman Saleh Malang 
dalam Peraturan Daerah, yakni Peraturan Daerah Provinsi Jawa Timur Nomor 10 Tahun 2012 Tentang Pengelolaan Bandar Udara Abdulrachman Saleh Malang.

Dengan dikeluarkannya Keputusan Menteri Perhubungan tersebut, maka dapat dilakukan analisa sebagai berikut. Analisa awal yaitu mengenai bentuk pelimpahan kewenangan. Sebagaimana telah dipaparkan dalam sub-bab sebelumnya mengenai hubungan antara desentralisasi dan dekonsentrasi, diketahui bahwa dekonsentrasi sesungguhnya adalah bagian dari desentralisasi. Oleh karena itu model pelimpahan kewenangan dalam dekonsentrasi sama dengan pelimpahan kewenangan dalam desentralisasi yaitu delegasi. Delegasi mengandung arti penyerahan wewenang dari pejabat yang lebih tinggi kepada yang lebih rendah. Penyerahan yang demikian dianggap tidak dapat dibenarkan selain dengan atau berdasarkan kekuatan hukum. Delegasi selalu dituntut adanya dasar hukum karena apabila pemberi delegasi (delegan) ingin menarik kembali wewenang yang telah didelegasikannya, maka harus dengan peraturan perundangundangan yang sama. Wewenang yang diperoleh dari delegasi itu dapat pula disubdelegasikan kepada subdelegatoris. Untuk subdelegatoris ini berlaku sama dengan ketentuan delegasi. Wewenang yang diperoleh dari atribusi dan delegasi dapat dimandatkan kepada organ atau pegawai-pegawai bawahan bilamana organ atau pejabat yang secara resmi memperoleh wewenang itu tidak mampu melaksanakan sendiri wewenang tersebut.

Menurut Heinrich Triepel ${ }^{29}$, pendelegasian dalam pengertian hukum publik dimaksudkan tindakan hukum pemangku suatu wewenang kenegaraan. Jadi, pendelegasian ini merupakan pergeseran kompetensi, pelepasan dan penerimaan sesuatu wewenang, yang keduanya berdasarkan atas kehendak pihak yang menyerahkan wewenang itu.

Heinricht membedakan pengertian delegation dalam echte delegation dan unechte delegation. Echte delegation adalah sebagai pendelegasian sesungguhnya,

\footnotetext{
${ }^{29}$ Heinrich Triepel, Delegation und Mandat Im-ofeentlichen Recht, Stuttgart, Berlin, 1942, h. 23 sebagaimana dikutip Agussalim Andi Gadjong, Op. Cit., Penerbit Ghalia Indonesia, Bogor, 2007, h. 104.
} 
yang dinamakan juga devolvierende delegation atau translative delegation, yang diartikan pelepasan wewenang bersamaan dengan penerimaan suatu kompetensi. ${ }^{30}$

Echte delegation mempunyai modifikasi, yaitu apabila suatu pendelegasian timbul dari perkembangan suatu mandat (seperti dalam negara monarki absolut, bahwa hakim memperoleh suatu kekuasaan peradilan sebagai mandatarais raja). Sedangkan unechte delegation diartikan sebagai pendelegasian tak sesungguhnya yang diperinci dalam konservirende delegation. Konservirende delegation dimaksudkan sebagai jenis pendelegasian dengan menyerahkan sesuatu kompetensi, tetapi pemangku kekuasaan yang asli sama berwenangnya dengan yang memperoleh kompetensi itu. Pendelegasian dalam hal ini bukan untuk pembebasan sepenuhnya, melainkan untuk peringanan dari suatu beban kerja. Pendelegasian ini bukan suatu pendelegasian dengan syarat dapat ditarik kembali, karena yang mendelegasikan masih tetap berwenang seperti sediakala. Si penerima tidak melakukan tugas atas nama si pemberi, melainkan atas namanya sendiri. $^{31}$

Pendelegasian seperti demikian justru menciptakan dua pemangku dengan satu wewenang yang sama, tetapi wewenang pihak yang mendelegasikan menjadi pasif dan wewenang pihak yang menerima pendelegasian menjadi aktif. Jadi, hakikatnya terletak dalam hal bahwa pihak yang mendelegasikan tidak kehilangan kompetensinya, melainkan kehilangan monopoli dalam pelaksanaannya, misalkan pendelegasian kekuasaan perundang-undangan. ${ }^{32}$

Jika dikaitkan dengan Keputusan Menteri yang dijadikan dasar pelimpahan kewenangan pengelolaan bandar udara Abdurrahman Saleh Malang sebagaimana dipaparkan sebelumnya, maka kritik yang dapat diajukan adalah apakah tepat jika kewenangan Pemerintah (dalam hal ini Presiden) ketika mendekonsentrasikan kewenangannya justru dilakukan oleh Menteri? Jika hubungan kewenangan antara Presiden dan Menteri adalah delegasi, maka menjadi salah kaprah ketika pelimpahan dekonsentrasi tersebut dilakukan dengan Keputusan Menteri. Karena

\footnotetext{
${ }^{30}$ Ibid.

${ }^{31}$ Mustamin Dg Matutu, dkk,. Op. Cit., h. 138-139.

${ }^{32}$ Ibid.
} 
menurut Alf Ross (pakar Perancis) ${ }^{33}$, terdapat asas delegate potestas non potest delegare, yang berarti bahwa kekuasaan yang didelegasikan tidak boleh didelegasikan lagi. Namun jika hubungan kewenangan antara Presiden dan Menteri adalah mandat, maka hal tersebut juga tidaklah tepat. Karena tidak mungkin suatu kewenangan mandat dapat didelegasikan kepada organ pemerintahan yang lain.

Menyambung dari apa yang disampaikan Heinrich, maka menurut hemat penulis, hubungan kewenangan antara Presiden dan menteri sesungguhnya adalah bentuk unechte delegation. Dalam referensi lain, disebutkan sebagai delegasi semu (pseudo-delegation). Artinya yaitu pelimpahan kewenangan dari Presiden kepada Menteri sejatinya dimaksudkan sebagai jenis pendelegasian dengan menyerahkan sesuatu kompetensi, tetapi Presiden sama berwenangnya dengan yang memperoleh kompetensi itu (Menteri). Pendelegasian dalam hal ini bukan untuk pembebasan sepenuhnya, melainkan untuk peringanan dari suatu beban kerja. Pendelegasian ini bukan suatu pendelegasian dengan syarat dapat ditarik kembali, karena yang mendelegasikan masih tetap berwenang seperti sediakala. Dengan adanya model seperti itu, maka tidak menjadi masalah ketika pelimpahan kewenangan dekonsentrasi tersebut dilakukan oleh Menteri, pun demikian juga tidak ada asas yang dilanggar, khususnya asas delegate potestas non potest delegare.

Analisa selanjutnya yaitu berkaitan dengan figur hukum Keputusan yang menjadi dasar pelimpahan dekonsentrasi. Dalam praktek, seringkali terjadi jumbu penggunaan nomenklatur keputusan dengan peraturan, karena secara faktual masih banyak Keputusan yang susbstansinya justru bersifat mengatur.

Mengenai penggunaan istilah "keputusan" dan "peraturan", Jimly Asshiddiqie ${ }^{34}$ menyebutkan bahwa negara sebagai organisasi kekuasaan umum dapat membuat tiga macam keputusan yang mengikat secara hukum bagi subjeksubjek hukum yang terkait dengan keputusan-keputusan itu, yaitu keputusankeputusan yang bersifat umum dan abstrak (general and abstract) biasanya bersifat mengatur (regeling), sedangkan yang bersifat individual dan konkret

\footnotetext{
${ }^{33}$ American Journal of Comparative Law, 1958, Vol. 7, h. 13.

${ }^{34}$ Jimly Asshiddiqie, Perihal Undang-Undang, Rajawali Press, Jakarta, 2010, h. 9.
} 
dapat merupakan keputusan yang bersifat atau berisi penetapan administratif (beschikking) ataupun keputusan yang berupa „vonis" hakim yang lazimnya disebut dengan istilah putusan.

Oleh karena itu menurut Jimly ${ }^{35}$, ada tiga bentuk kegiatan pengambilan keputusan yang dapat dibedakan dengan penggunaan istilah "peraturan", "keputusan/ketetapan" dan "tetapan". Menurut Jimly, istilah-istilah tersebut sebaiknya hanya digunakan untuk:

1. Istilah "peraturan" digunakan untuk menyebut hasil kegiatan pengaturan yang menghasilkan peraturan (regels).

2. Istilah "keputusan" atau "ketetapan" digunakan untuk menyebut hasil kegiatan penetapan atau pengambilan keputusan administratif (beschikkings).

3. Istilah "tetapan" digunakan untuk menyebut penghakiman atau pengadilan yang menghasilkan putusan (vonnis).

Namun, sebagaimana dijelaskan Jimly ${ }^{36}$, memang penggunaan istilah-istilah tersebut dalam praktik tidak terjadi suatu keseragaman, misalnya dalam menyebut "tetapan" menggunakan istilah "keputusan hakim". Dari penjelasan Jimly tersebut maka dapat disimpulkan bahwa pengertian istilah "keputusan" dapat diartikan secara luas dan sempit. Dalam pengertian istilah "keputusan" yang luas, di dalamnya terkandung juga pengertian "peraturan / regels", "keputusan / beschikkings" dan "tetapan / vonnis". Sedangkan, dalam istilah "keputusan" dalam arti yang sempit, berarti adalah suatu hasil kegiatan penetapan atau pengambilan keputusan administratif (beschikkings).

Mengenai perbedaan antara keputusan (beschikking) dengan peraturan (regeling), Jimly Asshiddiqie menyebutkan bahwa keputusan (beschikking) selalu bersifat individual dan kongkrit (individual and concrete), sedangkan peraturan (regeling) selalu bersifat umum dan abstrak (general and abstract). ${ }^{37}$ Yang

\footnotetext{
${ }^{35}$ Ibid, h. 10 .

${ }^{36}$ Ibid, h. 11 .

${ }^{37}$ Jimly Asshiddiqie, Hukum Acara Pengujian Undang-Undang, Konpres dan Wtampone Press, Jakarta, 2005, h. 2.
} 
dimaksud bersifat general and abstract, yaitu keberlakuannya ditujukan kepada siapa saja yang dikenai perumusan kaedah umum.

Selain itu, menurut Maria Farida menyebutkan bahwa suatu keputusan (beschikkiking) bersifat sekali-selesai (enmahlig), sedangkan peraturan (regeling) selalu berlaku terus-menerus (dauerhaftig). ${ }^{38}$ Lebih jauh, Jimly menyatakan bahwa produk keputusan digugat melalui peradilan tata usaha negara, sedangkan produk peraturan diuji (Judicial review) langsung ke Mahkamah Agung atau kalau untuk undang-undang diuji ke Mahkamah Konstitusi. ${ }^{39}$

Berdasarkan uraian tersebut, maka menurut penulis penggunaan figur hukum Keputusan Menteri Perhubungan sebagai dasar pelimpahan kewenangan dekonsentrasi dalam hal pengelolaan bandar udara Abdurahman Saleh tidaklah tepat karena substansi dalam Keputusan tersebut berisi pengaturan, sehingga lebih tepat jika menggunakan nomenklatur peraturan. Walaupun demikian, Keputusan Menteri tersebut haruslah tetap dipandang sebagai peraturan. Hal ini dibenarkan berdasarkan Pasal 100 Undang-Undang Nomor 12 Tahun 2011 tentang Pembentukan Peraturan Perundang-Undangan (UU No. 12/2011) yang berbunyi :

"Semua Keputusan Presiden, Keputusan Menteri, Keputusan Gubernur, Keputusan Bupati/Walikota, atau keputusan pejabat lainnya sebagaimana dimaksud dalam Pasal 97 yang sifatnya mengatur, yang sudah ada sebelum Undang-Undang ini berlaku, harus dimaknai sebagai peraturan, sepanjang tidak bertentangan dengan Undang-Undang ini."

\section{PENUTUP}

\section{Kesimpulan}

Dalam penyelenggaraan sistem pemerintahan di Indonesia, ada 2 (dua) fungsi dasar yang melekat pada Gubernur. Pertama, yaitu fungsi desentralisasi. Dalam kaitannya dengan fungsi ini, Gubernur berkedudukan sebagai Kepala Daerah Otonom, yang memiliki kewenangan untuk menjalankan urusan rumah tangga daerah dengan sumber pendanaan APBD. Kedua, yaitu fungsi dekonsentrasi. Dalam kaitannya dengan fungsi ini, Gubernur berkedudukan

\footnotetext{
${ }^{38}$ Maria Farida Indrati Soeprapto, Ilmu Perundang-Undangan I : Jenis, Fungi, Materi Muatan, Kanisius, Yogyakarta, 2007, h. 78.

${ }^{39}$ Ibid., h. 28.
} 
sebagai Wakil Pemerintah Pusat, yang memiliki kewenangan untuk menjalankan urusan pemerintahan (absolut maupun umum) dengan sumber pendanaan APBN. Ada 3 (tiga) aspek yang menarik untuk dikaji lebih lanjut dalam kaitannya dengan implementasi dekonsentrasi, yaitu mengenai unit pelaksana, dasar hukum untuk melimpahkan, dan model pelimpahan kewenangan. Unit pelaksana berkaitan dengan organ/pejabat mana yang berwenang menyelenggarakan tugas-tugas dekonsentrasi yang dilimpahkan kepada daerah. Dasar hukum untuk melimpahkan berkaitan dengan figur hukum yang digunakan sebagai landasan yuridis bagi pemerintah dalam melegitimasi pelimpahan kewenangan tersebut. Sedangkan model pelimpahan kewenangan terkait erat dengan pejabat mana yang dibebani pertanggungjawaban dalam penyelenggaraan tugas dekonsentrasi.

\section{Saran}

Segera dibuatnya peraturan pelaksanaan dari UU No. 23/2014 khususnya mengenai Peraturan Pemerintah dalam kaitannya dengan perangkat Gube sebagaimana diatur dalam UU No. 23/2014.

\section{DAFTAR BACAAN}

Asshiddiqie, Jimly. Hukum Acara Pengujian Undang-Undang, Konpres dan Wtampone Press, Jakarta, 2005.

Asshiddiqie, Jimly. Perihal Undang-Undang, Rajawali Press, Jakarta, 2010.

BC. Smith, , Decentralization : The Territorial Dimension of State, George Allen and Urwin, Hemstead, 1985.

Gadjong, Agussalim Andi. Pemerintahan Daerah : Kajian Politik dan Hukum, Penerbit Ghalia Indonesia, Bogor, 2007.

Gie, The Liang. Pertumbuhan Pemerintahan Daerah di Negara Republik Indonesia, Liberty, Yogyakarta, 1967.

Hadiwijoyo, Suryo Sakti. Gubernur : Kedudukan, Peran dan Kewenangannya, Graha Ilmu, Yogyakarta, 2011.

Hofman, Bert. Indonesia: Decentralization- Opportunities and Risks, IMF and World Bank Resident Mission, 2000. 
Hoessein, Bhenyamin. Hubungan Penyelenggaraan Pemerintahan Pusat dengan Pemerintahan Daerah, Jurnal Bisnis dan Birokrasi No. 1/I/2000.

Indra, Mexsasai. Dinamika Hukum Tata Negara Indonesia, Refika Aditama, Bandung, 2011.

Kartasapoetra, R. G. Sistematika Hukum Tata Negara, Bina Aksara, Jakarta, 1987

Koirudin, Sketsa desentralisasi di Indonesia, Format Masa Depan Otonomi Menuju Kemandirian Daerah, Averroes Press, Malang, 2005.

Koswara, E. Otonomi Daerah : Untuk Demokrasi dan Kemandirian Rakyat, Yayasan PARIBA, Jakarta, 2001.

Larmours and Qalo (Ed), Decentralization in The South Pacific, Papua New Guinea : University of The South Pacific, 1985.

Litvack, Jennie, Juaid Ahmda, Richard Bird, Indonesia: DecentralizationOpportunities and Risks. IMF and World Bank Resident Mission.

Manan, Bagir. Hubungan Antara Pusat dan Daerah Berdasarkan Asas Desentralisasi Menurut UUD 1945, Disertasi, UNPAD, Bandung, 1990.

Maryanov, Gerald S. Decentralization in Indonesia as a Political Problem, Interim Report Series Modern Indonesia Project, South-East Asia Program, Department of Far Eastern Studies, New York, Cornel University, Ithaca, 1958.

Marzuki, HM. Laica. Berjalan-Jalan di Ranah Hukum, Sekjen dan Kepaniteraan Mahkamah Konstitusi RI, Jakarta, 2006.SM, Oentarto. Menggagas Format Otonomi Daerah Masa Depan, Samitra Media Utama, Jakarta, 2004.

Matutu Mustamin Dg, dkk. Mandat, Delegasi, Atribusi, dan Implementasinya di Indonesia, UII Press, Yogyakarta, 2004.

Mawhood, Philip (ed), Local Government in The Third World : The Experience of Tropical Africa, Wiley, Chichecter, London-UK, 1983.

Situmorang, Sodjuangon. Model Pembagian Urusan Pemerintahan Antara Pemerintah, Provinsi dan Kabupaten/Kota, Disertasi, FISIP PPS UI, Jakarta, 2002.

Smith, BC. Decentralization : The Territorial Dimension of The State, Asia Publishing House, London, 1985.

Soehino, Asas-Asas Hukum Tata Pemerintahan, Liberty, Yogyakarta, 1984. 
Soeprapto, Maria Farida Indrati. Ilmu Perundang-Undangan I : Jenis, Fungi, Materi Muatan, Kanisius, Yogyakarta, 2007.

Suradinata, Ermaya. Kebijaksanaan Pembangunan dalam Pelaksanaan Otonomi Daerah, Ramadan, Bandung, 1993.

Syafrudin, Ateng. Pasang Surut Otonomi Daerah, Bina Cipta, Bandung, 1985.

Tresna, R. Bertamasya Ke Taman Ketatanegaraan, Dibya, Bandung, Tanpa Tahun.

Triepel, Heinrich. Delegation und Mandat Im-ofeentlichen Recht, Stuttgart, Berlin, 1942, h. 23 sebagaimana dikutip Agussalim Andi Gadjong, Op. Cit., Penerbit Ghalia Indonesia, Bogor, 2007.

\section{Peraturan Perundang-Undangan :}

Undang-Undang Dasar Negara Republik Indonesia Tahun 1945

Undang Nomor 22 Tahun 1948 tentang Penetapan Aturan-Aturan Pokok Mengenai Pemerintahan Sendiri Di Daerah-Daerah Yang Berhak Mengatur Dan Mengurus Rumah Tangganya Sendiri

Undang-Undang Nomor 1 Tahun 1957 tentang Pokok-Pokok Pemerintahan Daerah

Undang-Undang Nomor 18 Tahun 1965 tentang Pokok-Pokok Pemerintahan Daerah

Undang-Undang Nomor 5 Tahun 1974 tentang Pokok-Pokok Pemerintahan Di Daerah

Undang-Undang Nomor 22 Tahun 1999 tentang Pemerintahan Daerah Undang-Undang Nomor 32 Tahun 2004 tentang Pemerintahan Daerah Undang-Undang Nomor 12 Tahun 2011 tentang Pembentukan Peraturan Perundang-Undangan

Undang-Undang Nomor 23 Tahun 2014 tentang Pemerintahan Daerah

Peraturan Pemerintah Nomor 19 Tahun 2010 tentang Tata Cara Pelaksanaan Tugas Dan Wewenang Serta Kedudukan Keuangan Gubernur Sebagai Wakil Pemerintah Di Wilayah Provinsi

Peraturan Pemerintah Nomor 23 Tahun 2011 tentang Perubahan Atas Peraturan Pemerintah Nomor 19 Tahun 2010 